\title{
A Corpus-based Transitivity Analysis of Nilopher's Character in The Stone Woman
}

\author{
* Muhammad Ilyas Mahmood (Corresponding Author) \\ ** Muhammad Ahmad Hashmi
}

\begin{abstract}
The present study focuses on the use of transitivity as a tool to explore characterization. Transitivity works as a tool to analyze the depiction of people's actions at a broader level (Halliday, 1994). A significant number of studies have been done using the system of transitivity in understanding the narratives to highlight the ideological function of language (Rashid, 2016). The objective of the current study is to use the device of transitivity in highlighting the character of Nilopher in the novel "The Stone Woman". The corpus of the novel has been tagged using Stanford Log-linear Parts of Speech (POS) tagger and the list of verbs has been extracted. Each verb has been marked with its respective process 'material', 'mental', 'behavioral', 'verbal', 'relational' or 'existential'. After it, each verb has been analyzed in its particular clause using concordance. The clause structure analysis of each process shows that Nilopher has been portrayed as an assertive character. The grammatical choices of the writer help us to conclude the fickle and lustful nature of Nilopher. Moreover, it has been concluded that the character of Nilopher is developed as an emotional character with tender but corrupt nature, and covet behavior. The combination of material process verbs with specific goals and circumstances elements lead us to perceive her tender but corrupt nature. Furthermore, the transitivity analysis of mental and behavioral process verbs, explores her covet and yearning behavior. The current study is important pedagogically to understand literature with logic and evidence because transitivity analysis establishes a demonstrable fact. It will also help the writers to apply the system of transitivity with an intelligent use of language choices in portraying characters and discourse of social interaction.
\end{abstract}

Keywords: Transitivity Analysis, Characterization, Language Choices, Participants, Processes Introduction

The purpose of the present study is to use the tool of transitivity in understanding characterization. For this purpose, we have chosen one of the major characters Nilopher from the novel The Stone Woman. The system of transitivity explores the depiction of people by analyzing their actions at a broader level (Halliday, 1994). This system works with the study of the grammar of clause structure by defining participants/ agents, processes, and objects. Researchers have chosen the character of Nilopher because it is the second-longest character, which also serves as the narrator of the novel. To analyze the character of Nilopher, it is necessary to study the language choices, which Tariq Ali has associated with her character.

According to Halliday, the grammar of language plays a key role to portray any character in particular social circumstances. In this way, the choice of language is very important. According to Halliday (1978), the language serves a function to reflect the social life of human beings so, the internal organization of language is meaningful and systematic. Moreover, the analysis of fiction under the umbrella of transitivity is a bit difficult, because the characters in fiction are interlinked and are developed gradually with the narrative, which makes its analysis more complex.

Abrams and Harpman (2008) argue that literary genre consists of characters, which are explored by the readers from the events, actions, and happenings in a specific time and space. Hence, the current study deals with the structure of clauses, which are coded and identified as a character of Nilopher. Then, these clauses have been analyzed looking at the particular context of the novel with an independent analysis of processes. The combination of contextual analysis along with the realization of processes helped to explore the character of Nilopher. It means the analysis of linguistic items with a particular context can be the biases to understand the social roles of characters in the novel.

* Centre for English Language and Learning, University of Okara, Pakistan Email: ilyas.edu.tesl@gmail.com

** University of Okara, Pakistan Email: muhammadahmadhashmi@gmail.com 


\section{Research Question}

How has the device of transitivity been used in the development of Nilopher's character?

In what way has the writer used the transitivity device in the development of Nilopher's character?

\section{Significance of the study}

The present study is significant as it addresses the writer's view in an effective usage of transitivity device. It also helps the reader in understanding the text, keeping in mind the system of transitivity. It also proves fruitful pedagogically for teachers to explore the literature with logic and evidence.

\section{Methodology}

\section{Data Collection}

The current study is corpus-based. The text of the novel has been used as a corpus. Then, it was tagged using Stanford Log-linear Part-Of-Speech Tagger. After it, the tags of verbs have been separated using an online corpus tool Laurence Anthony's AntConc software 3.5.7.

\section{Data Analysis}

The process of each verb has been decided by using the Hallidyian concept of transitivity as follows (Halliday, 1994).

\section{Theoretical Framework}

Material process: These are the processes of doing having 'doer', 'goal', 'beneficiaries' as participants.

Mental Process: These processes are of sensing through perception, reaction, cognition with 'sensor' (or experiencer) and phenomena as participants.

Verbal process: These are processes of saying having 'sayer', 'receiver', and 'verbiage' as participants.

Behavioral process: It is the combination of mental and verbal processes with 'behaver' as a participant.

Existential process: These processes demonstrate existence with empty particles 'there'.

Relational process: These are processes of 'being' where participants are used to effect by other participants in one way or in another way. The participants are 'carriers' or 'attributers'.

After that, each verb has been analyzed in its particular clause structure to decide the participants using the concordance generator: a tool of AntConc. Finally, the results have been generated.

\section{Results and Interpretations}

The corpus-based analysis of "The Stone Woman" shows that the writer has associated the total 338 processes with one of the major characters Nilopher, who acts as a narrator of the novel. The writer has associated $52.37 \%, 26.92 \%, 10.35 \%, 10.06 \%$ material, mental, verbal, and behavioral process verbs respectively. Existential and relational processes are not associated with this character. The graphical representation of these processes is shown below.

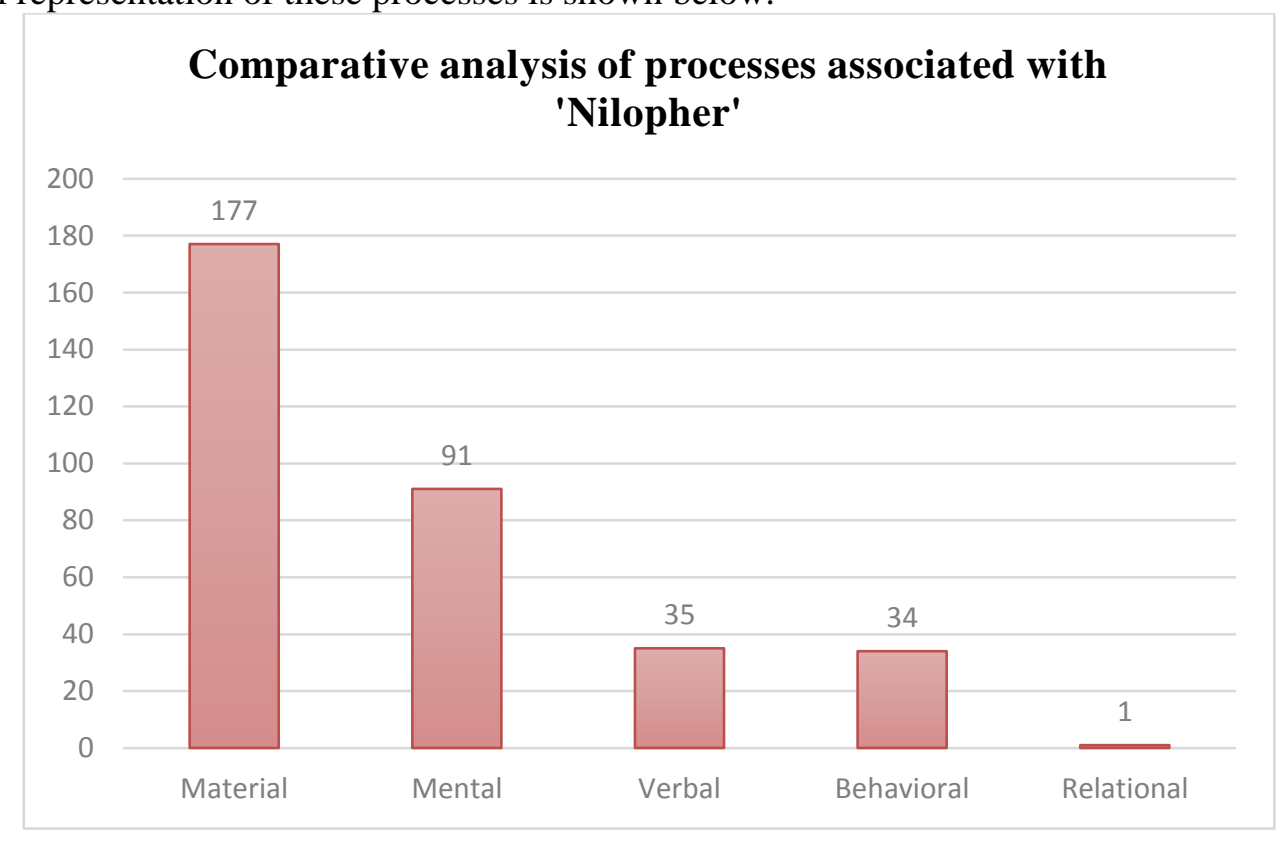


According to Halliday material process verbs are of two kinds. The process of 'doing', which the actor does with attention and willingness. On the other hand the process of 'happening', which has to be faced by the character without knowing his/her will. Here, Ali has associated a total of 177 material process verbs with $90 \%$ 'doing' processes and $10 \%$ 'happening' processes.

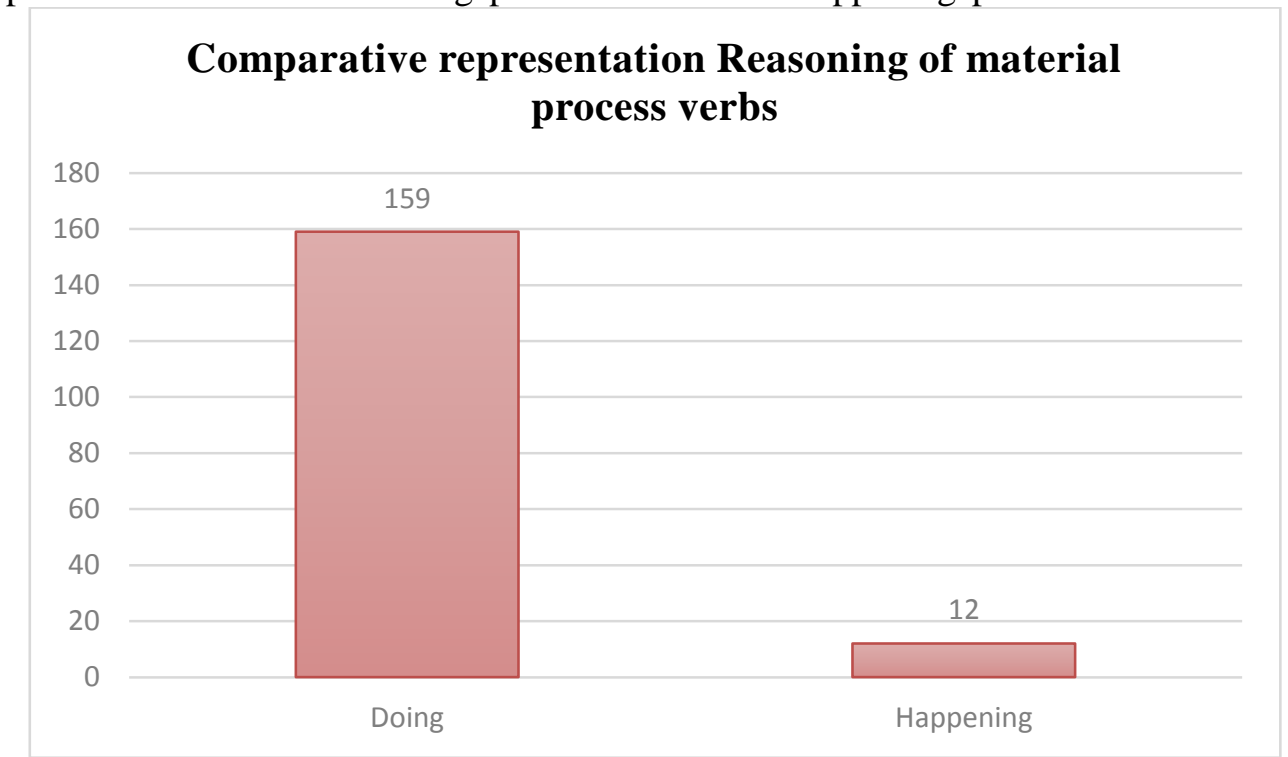

Based on transitivity analysis, the characteristics related to Nilopher's character have been tried to highlight using the text of the novel as a source. The interpretations are purely based on the analysis of processes in their respective clauses. So, the following elements have been explored in the character of Nilopher using transitivity as a tool.

\section{Assertive Character}

Contrary to the other major and minor characters, Nilopher is found the only assertive character after the leading and forceful character of Iskander Pasha. Ali has used material process verbs interrupt (2 times) and snatched; verbal process verbs asked, signaled, and referred to portray Nilopher as an assertive character. The verbal process verb ask shows a commanding attitude (Cole \& Shaw, 1974); signaled serves as a forceful verb of warning (Delbecque \& Gorp, 2015) and the material process verb snatched exhibits a kind of violent behavior (Yasuhito). The analyses of these processes along with their participants explores her confidence, boldness, and self-possessed nature. All the verbs have been used actively with Nilopher as an 'actor' at these stances. The usage of the first-person pronoun $I$ in all the dialogues shows her boldness.

$\begin{array}{llll}\text { Actor } & \text { Process: material } & \text { Goal } & \\ \text { I } & \text { interrupted } & \text { her } & \\ \text { Actor } & \text { Process: } \text { material } & \text { Goal } & \text { Range } \\ \text { I } & \text { had referred } & \text { to the spy As a eunuch-general. } \\ \text { Actor } & \text { Process: } \text { material } & \text { Goal } & \\ \text { I } & \text { snatched } & \text { the notebook away from him, }\end{array}$

The nature of 'goal' in the above sentence is her (Sara), spy, him (Byron), and Zeynep indicates her superior attitude with other characters.
Senser
Process: mental
Process: material
Phenomena
She decides
to marry
Him.

Ali has chosen very unique mental process verbs like decides (6 times) which interprets her nature to control the situation (Stowe, 1986) with taking decisions. In her teenage, she decided to live an independent life with her chosen boyfriend against the will of her father Iskander Pasha. She has got an inner power to have her own decisions. She thinks very positively and does not want to create any trouble for her family especially her two brothers Salman and Halil.

$\begin{array}{lll}\text { Senser } & \text { Process: } \text { mental } & \text { Phenomena } \\ \text { I } & \text { was considered } & \text { Mature enough to be told the official version. }\end{array}$


The 'phenomena' of the above sentence mature enough to be told the official version adds the inner dealings of her, where she feels herself an adult one to have her independent life. She explained herself as a narrative of the novel.

\section{Senser Process: mental Phenomena \\ I had to decide The course of my life.}

Another example, where she is telling about her past life and wants to show herself a strong person, writer again uses a very blunt and bold 'mental process' verb decide (Stowe,1986) with 'phenomena' 'the course of my life'. She tells about her life. This is to create a strong view of past life. It looks that she tries to hide the regret, which she feels is a burden because she has been fed-up with Dimitri.

The 'verbal process' verb asked (2 times) shows an Inquiring behavior (Fotos \& Ellis, 1991); permit is imperative (Lee, 1975); insulted manifests the arrogant or scornful delight by speech or behavior(Taavitsainen \& Jucker, 2007); inquired, admired, bothered are used to disturb mental calm (Gawlicki, McKown, Talbert \& Brandt, 2014) and questioned are very commanding and forceful. The analysis of clause structure of the verbs in the following sentences unfold many realities

$\begin{array}{llll}\text { Sayer } & \text { Process: verbal } & \text { Receiver } & \text { Verbiage } \\ \text { I } & \text { will not permit } & \text { Selim } & \text { to be insulted by you } \\ \text { Sayer } & \text { Process: verbal } & \text { Receiver } & \text { Verbiage } \\ \text { I } & \text { told } & \text { Her } & \text { of my decision to marry Selim. }\end{array}$

Transitivity analysis of the above sentences shows the forceful attitude of Nilopher for her new boyfriend Selim. She does not want to hear any word against Selim. The 'verbal process' of the $1^{\text {st }}$ sentence above shows her negation and straightforwardness in the favor of Selim, which is very clear from the 'verbiage' of the same sentence above to be insulted by you. The verbiage of $2^{\text {nd }}$ sentence above explores her willingness again for a new love Selim of my decision to marry Selim. Here, the writer wants to show the fickle and corrupt behavior of females of that era. Ali tried to show the inconsistent nature of females in contrast to the consistent behavior of Iskander Pasha. Iskander Pasha remained loyal to his only love Zakiye throughout his life.

Nilopher tries to copy the authoritative moves of her father Iskander Pasha, whom she used to hate in her teenage. She becomes a calm and quiet person before Iskander Pasha and her tone changed as in the following sentences.

\section{Sayer Process: verbal Receiver Verbiage \\ I talked to Iskander Pasha that evening for many hours, and for the first time.}

Here, the verb talked is not very forceful, but a light way of interaction. It shows the dominant and authoritative influence of Iskander Pasha over Nilopher.

\section{Unstable Personality}

Tariq Ali has tried to portray Nilopher as a living character. The character of Nilopher represents the women in general. The material process verbs escape, leave are used to show the movement of agents (Chatterjee, Southwood \& Basilico,1999) away from the patient; become, poured, shuddered; mental process verbs wanted interpreting desire (Werth,1998); hated (3 times) expounding extremely negative feeling (Berkowitz, 2005) and phrasal verb tired of (6 times) illustrate Nilopher's changing character.

$\begin{array}{llll}\text { Senser } & \text { Process: mental } & \text { Process: material } & \text { Goal } \\ \text { She } & \text { decides } & \text { to marry } & \text { him. }\end{array}$

Nilopher is shown an unstable personality, who wants; whatever she likes. First, she married to Dmitri and got children from him. Later, she wants to marry Selim. Transitivity analysis of above 'mental process verb' decides which is and 'material process verb' merry is very compelling and strong as have already been explained in the above paragraphs. Ali explores the inconsistent nature of females in that era even in very consistent matters.

$\begin{array}{lll}\text { Actor } & \text { Process: material } & \text { Goal } \\ \text { Tears } & \text { poured down } & \text { My cheeks. }\end{array}$

The emotional nature of females has been portrayed very beautifully in the sentence above. Transitivity analysis of material process verb poured down in combination with 'actor' tears which is 
more likely used to arouse pain (Carmichael\& Campling,1991)and 'goal' cheeks is very impressive. Nilopher has been portrayed as a character, who loves others and does care for others but the only problem is her inconsistent nature.

At many stances, she becomes angry with her husband Dimitri, with whom she has got eloped against the will of her father.

\section{Senser \\ I}

\section{Senser}

Senser

Senser

Senser

Senser

I
Process: mental

was tired of

Process: mental

Tired

Process: mental

Tired

Process: mental

Tired

Process: mental

Tired of seeing

Process: mental

had tired

\section{Phenomena}

Dmitri.

\section{Phenomena}

of his jokes.

Phenomena

of his bad poetry.

Phenomena

of his resentments.

\section{Phenomena}

him wear the same style of clothes every single day

\section{Phenomena}

of his body.

Nilopher utters 'mental process verb' tired' six times for Dmitri to show her mental sickness (Gusmer, 1984). Transitivity analysis of 'phenomena' in the above sentences unfolds Nilopher's variant nature. Nilopher has been done with her husband. He is nothing more than a tiresome person for her. She mentions his jokes, his bad poetry, his resentments, his style of clothes, and even his body. Life is nothing but a materialist entity for Nilopher. She has tired of her husband buying glasses, wearing old fashioned clothes, and reading bad poetry. The transitivity analysis explores her fickle nature. The last sentence above adds a very strong meaning in transitivity analysis. Ali mentions Nilopher (I) as a 'sensor' and 'phenomena' of his body with a wise combination of 'mental process verb' tried to paint an erratic picture of women of that century in general.

Due to her voluptuous nature, she falls in love with other males. This shows her amoral and corrupt nature.

$\begin{array}{lll}\text { Senser } & \text { Process: mental } & \text { Phenomena } \\ \text { I } & \text { Hated } & \text { Him } \\ \text { Senser } & \text { Process: mental } & \text { Phenomena } \\ \text { I } & \text { Hated } & \text { his narrow-mindedness. } \\ \text { Senser } & \text { Process: mental } & \text { Phenomena }\end{array}$

I hated the way he treated my brothers and especially Halil.

Transitivity analysis of the above sentences represents the Nilopher as a 'sensor' with her emphasis on 'mental process verb' hated, which exhibits an extremely negative feeling (Berkowitz, 2005). The 'phenomena' him, his narrow-mindedness, and the way he treated my brothers and especially Halil refer to the actions of Iskander Pasha. It indicates the generation gap, where a father is unable to transport his views and the children are failed to understand their father, which finally results in unfavorable circumstances and unhealthy relationships.

\section{Provoking and Emotional/ Sentimental character}

The intelligent use of material process verbs burst out which is an interpretation of cry (van Valin, 2006); sobered refers to somebody serious and thoughtful (Paradis, 2001), filled, overcome, become, reflect, threw, filled, bade, and merry (3 times) points out the writer's intentions to show Nilopher as an emotional character. She explores her emotions spontaneously. She falls in love many times and remains open for everyone. The repetition of material process verbs Marry (3times) explores her lust.

$\begin{array}{llll}\text { Actor } & \text { Process: mental } & \text { Process: material } & \text { Goal } \\ \text { "I } & \text { want } & \text { to marry } & \text { you." }\end{array}$




$\begin{array}{lll}\text { Goal } & \text { Process: material } & \text { Range } \\ \text { I } & \text { 'm married } & \text { to someone else." }\end{array}$

Nilopher eloped with Dimitri a school teacher against the will of her father Iskander Pasha and then she had a desire to have voluptuous relations with Selim. This shows her sentimental nature and lecherous personality. The range of the above sentence to someone else explores the worth of her own decisions. Here, the writer has used the tool of passivation, to show her cleverness. She is smart enough to seek the attention of Selim, saying she was married to Dmitri.

$\begin{array}{lll}\text { Actor } & \text { Process: material } & \text { Goal } \\ \text { I } & \text { burst out } & \text { laughing. } \\ \text { Goal } & \text { Process: material } & \text { Range } \\ \text { I } & \text { was filled } & \text { with a very deep love for him. } \\ \text { Actor } & \text { Process: material } & \text { Goal } \\ \text { I } & \text { bade } & \text { an emotional farewell }\end{array}$

The 'goal' of the above sentences laughing which is an emotional attribute (Hellstén,1994), filled with a very deep love for him and an emotional farewell again shows her emotional personality. Yemelianova (2013) demonstrates a situation in his work "Interiorized Self-Evaluation as Explication of Self-Concep" using an example from the belles letters 'Dylan bade her farewell' explaining the grip of emotions over the human body. In contrast to the Ansah (2011), who has illustrated a situation of 'anger' metaphorically 'anger has filled me' to show a high level of anger and pain, the current situation explains a feeling of love and lust. These clauses carry material process verbs burst out, filled, and bade to create a high transitivity effect. This is to highlight the unstable and sentimental personality of women of that Muslim era. The mental process verbs want and wish show desire (Werth, 1998); overcome (2 times), remembered, love, and decides to highlight her covet and yearning behavior.

$\begin{array}{lll}\text { Senser } & \text { Process: mental } & \text { Phenomena } \\ \text { I } & \text { wanted } & \text { to be alone. } \\ \text { Senser } & \text { Process: mental } & \text { Phenomena } \\ \text { I } & \text { would want } & \text { him for a long time. } \\ \text { Senser } & \text { Process: mental } & \text { Phenomena } \\ \text { Nilofer } & \text { is overcome } & \text { by longing for Selim }\end{array}$

The 'mental process verb' want above shows her desire (Werth, 1998) to be in illegal relations with other males. The transitivity analysis of the above sentences highlights the reality of her wishes. The phenomena of the above sentences him for a long time and by longing for Selim advocate her lusty and corrupt nature.

\section{Lustful Character}

The intelligent use of material process verbs kissed which explains a gentle way of making love (Manning, 1997: 54); cupping represents sexual desire (Freud 2005: 5); undress and dressed show the sexual intent (Keita \& Dyk, 2006); run away, meet, explored, blew, covered, and join strongly appeal the lust of Nilopher. She is found in voluptuous relationships with other males, even she already had kids of Drmitri. Transitivity analysis of these verbs explores that these are material process verbs with distinct goals. 'Actor' of these processes is Nilopher herself. The writer has chosen Nilopher to explore her character. She is very confident and bold having no fear or shame of being caught while doing these shameful activities. Even when she was unmarried, she practiced these relations with Dirmitri.

$\begin{array}{lll}\text { Actor } & \text { Process: material } & \text { Goal } \\ \text { she } & \text { is falling } & \text { in love with him. } \\ \text { Actor } & \text { Process: material } & \text { Goal } \\ \text { I } & \text { first kissed } & \text { Orhan's father. } \\ \text { Actor } & \text { Process: material } & \text { Goal } \\ \text { I } & \text { ran away } & \text { with Dmitri. }\end{array}$

The use of she in the first sentence above indicates her falling in love but someone else narrates the situation. The reason behind this can be her lament on her falling in love with a school 
teacher Dimitri. Here, the transitivity effect is not very high, because of $3^{\text {rd }}$ person pronoun. The use of the verb kiss serves to show the height of lustful intentions (Ngezem, 2009). In the second sentence above Nilopher admitted to kiss Dimitri before her marriage. Here the 'goal' Orhan's father has been used to produce less transitivity effect of her loose character before marriage. In $3^{\text {rd }}$ sentence above the description is very straightforward. 'Actors', 'processes', and 'goals' are very clear and Nilopher herself narrates these events about her shameful action of eloping with Dmitri. Nilopher is also shown as an honest character here, who is willing not to hide her evils. The other aspect can be the height of evil in that society, where people feel proud to describe their evil deeds.

$\begin{array}{lll}\text { Actor } & \text { Process: material } & \text { Goal Range } \\ \text { I } & \text { will meet } & \text { you tonight in the orchard } \\ \text { Actor } & \text { Process: material } & \text { Goal } \\ \text { We } & \text { began to explore } & \text { each other's bodies. } \\ \text { Actor } & \text { Process: material } & \text { Goal } \\ \text { I } & \text { Blew } & \text { him a kiss }\end{array}$

The clause structure analysis of the above sentences highlights her loose character. Her sexual activities play a corrupt picture of the woman of that era. She seduces other male characters and uses her body and beauty as a tool. Here the 'goal' of each other's bodies, him a kiss, and the 'range' of the $1^{\text {st }}$ sentence above tonight in the orchard are seductive. Moving ahead in the novel the situations become more intense and shocking when she practically does these acts.

\begin{tabular}{|c|c|c|c|}
\hline $\begin{array}{l}\text { Actor } \\
\text { I }\end{array}$ & $\begin{array}{l}\text { Process: material } \\
\text { entered }\end{array}$ & $\begin{array}{l}\text { Goal } \\
\text { my bed chamber }\end{array}$ & $\begin{array}{l}\text { Process: material } \\
\text { and pulled }\end{array}$ \\
\hline $\begin{array}{l}\text { Actor } \\
\text { We }\end{array}$ & $\begin{array}{l}\text { Process: material } \\
\text { began to explore }\end{array}$ & $\begin{array}{l}\text { Goal } \\
\text { each other's bodies. }\end{array}$ & \\
\hline Actor & Process: material & Goal & Circumstantial elements \\
\hline $\begin{array}{l}\text { Selim } \\
\text { and I }\end{array}$ & made & Love & in silence. \\
\hline
\end{tabular}

Ali depicts the corrupt and crooked values of that society. Nilopher serves as a symbol representing all the women of that era in general, where the family system has been corrupted to its heights. The material process verbs entered, began and love in combination with Nilopher's and Selim shows a high transitivity effect. The goals of the above sentences bluntly reflect the corrupt character of Nilopher.

$\begin{array}{lllll}\text { Sayer } & \text { Process: verbal } & \text { Actor } & \text { Process: material } & \text { Goal } \\ \text { I } & \text { screamed } & \text { and the hands } & \text { covered } & \text { my mouth. } \\ \text { Behaver } & \text { Process: behavioral } & \text { Actor } & \text { Process: material } & \text { Goal } \\ \text { I } & \text { felt } & \text { two gentle hands } & \text { cupping } & \text { my breasts. } \\ \text { Actor } & \text { Process: } \text { material } & \text { Goal } & \text { Process: material } & \text { Goal } \\ \text { you } & \text { can take } & \text { your clothes off } & \text { and come to } & \text { bed. }\end{array}$

The semantic analysis of linguistic items along with the contextual analysis of the above sentences carve a strong transitivity effect on the minds of readers. The combination of material process verbs screamed which denotes a kind of violence in sexual language (Cotterill,2007); covered and cupping with their respective 'goals' illustrate the height of lascivious relations with Selim. In the $3^{\text {rd }}$ sentence, the 'actor' is the $2^{\text {nd }}$ person you have been used in present tense takeoff. According to Struckman-Johnson and Anderson (2003) taking off the clothes is a kind of a category of emotional manipulation which leads to sexual arousal. The transitivity effect becomes stronger in the present tense process in comparison with past or future tense. Nilopher asks Selim to remove his clothes off.

$\begin{array}{lllll}\text { Actor } & \text { Process: material } & \text { Goal } & \text { Circumstantial elements } & \\ \text { We } & \text { had been deprived of } & \text { each other's company } & \text { for the whole day } & \\ \text { Actor } & \text { Process: } \text { material } & \text { Beneficiary } & \text { Process: material } & \text { Goal } \\ \text { I } & \text { was in bed waiting } & \text { for Selim to } & \text { undress and join } & \text { me. }\end{array}$

Here, the $1^{\text {st }}$ person has been changed in the $3^{\text {rd }}$ person [we] where she has been completely involved with Selim. She does not feel any regret for her actions. Even, she missed those sexual 
moments. The 'material process verb' of the $1^{\text {st }}$ sentence above deprived of shows her desire and lust and the 'range' shows the timeline for the whole day, which means each night she used to practice these actions. The material process verb waiting with a combination of 'actor' $I$ and 'circumstantial elements' on bed includes her wish to be with Selim.

The 'mental process verbs' provoked, aroused, want, flashed, felt and feeling demonstrate her inner-experiences and feeling of emotional excitement (Kuperman, Estes, Brysbaert \& Warriner, 2014; Russell \& Mehrabian, 1977; Warriner, Kuperman \& Brysbaert, 2013) and mental state of Nilopher, who is even the mother of Dimtri's children has feelings for Selim.

$\begin{array}{lll}\text { Senser } & \text { Process: mental } & \text { Phenomena } \\ \text { I } & \text { deliberately provoked } & \text { him. }\end{array}$

The strong mental process verb provoked adds a significant share in the development and illustration of Nilopher's mental condition. She thinks of Selim in alone. She wants to be with him every time, even she wants to marry him.

\section{Phenomena}

An image of his naked body

\section{Process: mental}

flashed

\section{Senser}

through my mind.

The mental process flashed indicates her sensory feelings for Selim. The transitivity effect is very strong because the 'sensor' here is Nilopher. The process signifies the open and clear image of Selim's naked body. All these stances help to portray Nilopher as a lustful and corrupt character.

\section{Intimacy with Mother}

Nilopher is shown very close to her mother. She has natural feelings of love for her. Ali has used material process verbs touched, leaned, kissed, (3 times), pressed (2 times), went, put, held...etc. to show her intimate relationship with her mother. The verb of perception touch indicates closeness (Borin, Forsberg \& Lönngren, 2013). She has become a daughter, who shares the pathos of her mother and helps her showing an affectionate and loving behavior.

$\begin{array}{lll}\text { Actor } & \text { Process: } \text { material } & \text { Goal } \\ \text { I } & \text { had never pressed } & \text { her feet }\end{array}$

'Actor' Nilopher wants to show extra love to her mother. This is because of the pity condition of her mother. When Nilopher was a teenage girl her mother lived in a very grave condition because of the rude and strict behavior of Iskander Pasha. She could not help her mother, but now she has become mature enough to talk to her mother directly. She met her after a long time. She shares her mother's pathos and tragedies.

$\begin{array}{lllll}\text { Actor } & \text { Process: material } & \text { Goal } & & \\ \text { I } & \text { ran to tell } & \text { Sara. } & & \\ \text { Actor } & \text { Process: material } & \text { Goal } & & \\ \text { I } & \text { put } & \text { my arms around her. } & \\ \text { Actor } & \text { Process: } \text { material } & \text { Goal } & \text { Process: material } & \text { Goal } \\ \text { I } & \text { held } & \text { her hands } & \text { and kissed } & \text { them. }\end{array}$

The analysis of 'goals' of the above sentences Sara, my arms around her and her hands explore her level of intimacy and love for her mother. The transitivity effect is strong here because of the clear cut goals and forceful processes. So, concluding all the above discussion, it can be said that the relation of Nilopher with her mother is very strong and looks pure. In contrast to the image of her father, she has had a soft corner for her mother.

\section{Sensitive Character}

Nilopher has been portrayed as a sensitive character. No doubt, she uses different tricks to allure other males but at the same time, she has also been shown as a sensitive lady. The mental and behavioral process verbs felt (3 times), looked (2 times), smiled, laughed, feel, wept and looking (2 times), show emotional response (Ponsonnet,2014) and her sensitive nature. Nature does have a strong and powerful effect upon her.

\section{Behaver I}

Senser

the music of the water

\section{Process: behavior was looking}

\section{Circumstances}

out of the window in a slight daze.

\section{Process: mental Phenomena}

soothes

me.

Here the 'circumstantial elements' out of the window in a slight daze and the music of water express the powerful effect of nature. 


$\begin{array}{lll}\text { Behaver } & \text { Process: behavior } & \text { Circumstances } \\ \text { I } & \text { looked } & \text { out at the sea. } \\ \text { Behaver } & \text { Process: behavior } & \text { Circumstances } \\ \text { I } & \text { first looked } & \text { out of the window that night. }\end{array}$

The behavioral process verbs looked in the above sentences along with the combination of circumstantial elements' out at the sea and out of the window that night inform about the involvement of nature upon Nilopher. It looks that after her lusty and crooked actions, she takes rest in the lap of nature to soothe herself.

\section{Love of Family}

During the clause structure analysis, it has been identified that Nilopher has a soft corner for her family with her two brothers Salman and Halil, mother Sara, and her son Orhan. Material process verbs, greet shows pleasure and pleasant effect (Oraiby, 2011); quickened, exchanged; behavioral process verbs seen, glimpsed, and mental process verbs want and like show her love and soft corner for her family throughout the novel. The association of meanings and nature of these processes with their relevant contexts show that Nilopher was closely attached to her brothers in her childhood. Nilopher hated her father in her childhood when he used to insult her brothers. Material process verb ran also contributes to the continuity of the passion and love for her brothers.

$\begin{array}{lllll}\text { Actor } & \text { Process: material } & \text { Goal } & \text { Process: material } & \text { Goal } \\ \text { I } & \text { ran } & \text { downstairs } & \text { to greet } & \text { them. }\end{array}$

The effectiveness of 'material process verb' ran which is a manner of motion (Rappaport Hovav\& Levin, 1998) highlights her eagerness to see her brothers after a long time. The verb greet is also showing her happiness for her brothers. Material process verbs stroked and kissed express love (Kang \& Wu, 2015) which she does have for her son Orhan.

\section{Actor Process: material Goal Process: material Goal}

I took off her dusty shoes and removed the socks from her feet.

The description of goals her dusty shoes and the socks from her feet shows a mother's love for her children. She loves her son a lot. Her love of family has been portrayed by Ali using the material process verbs missed (2 times) and wanted which are emotional verbs in nature (Hartshorne, Pogue \& Snedeker, 2015). She acts as a 'sensor' while expressing her feelings for her family.

\section{Senser Process: mental Phenomena}

I missed the summers here, in this house.

Ali depicted the character of Nilopher as a living and natural in all situations and developed her character as every woman of that society. In this way, the transitivity analysis leads us to the conclusion that Nilopher is the character, who loves and has a kind of affection, attachment, and love for her mother, siblings, and children.

\section{Conclusion}

The present study unfolds the character of Nilopher using the system of transitivity as a tool. This study foregrounds the writer's grammatical choices in developing the character of Nilopher. Ali has portrayed Nilopher as a second major character, who is in action with $52.37 \%$ material process verbs. The usage of mental process verbs with parallel action helps her to be an assertive character. The inconsistency and unstable personality has been portrayed by Ali to depict the woman of that era in general. Transitivity analysis of specific grammatical choices explores Nilopher's fickle nature. The generation gap has also been highlighted using certain mental and material process verbs. Moreover, Nilopher is also characterized as an emotional and sentimental character using the tool of passivation. Furthermore, transitivity analysis of clause structure explores Nilopher's covet and yearning behavior. Ali has chosen very forceful material process verbs falling, kissed, run away, meet, entered, explored, blew, cupping, covered, dressed, undress, and join with very effective 'goals' and 'circumstantial elements' to show the lusty and corrupt nature of Nilopher. Through the character of Nilopher, Ali portrayed all the women of that society in general. Nilopher is also found loving woman, who cares for her mother and brothers against the rude and strict behavior of her father Iskander Pasha. The tempting and lustful nature of Nilopher has been highlighted with the study of powerful mental and behavioral process verbs. Finally, it can be concluded that transitivity analysis of language choices in clause structure can help to reveal and unfold the true spirit of characterization. 


\section{References}

Abrams, M. H., \& Harpham, G. (2011). A glossary of literary terms. Cengage Learning.

Ansah, G. N. (2011). Emotion language in Akan: The case of anger. Encoding emotions in African languages, $119-157$.

Berkowitz, L. (2005). On hate and its determinants: Some affective and cognitive influences. The psychology of hate, 155-183.

Borin, L., Forsberg, M., \& Lönngren, L. (2013). SALDO: a touch of yin to WordNet's yang. Language resources and evaluation, 47(4), 1191-1211.

Carmichael, K., \& Campling, J. (1991). Women and Tears. In Ceremony of Innocence (pp. 61-79). Palgrave Macmillan, London.

Chatterjee, A., Southwood, M. H., \& Basilico, D. (1999). Verbs, events, and spatial representations. Neuropsychologia, 37(4), 395-402.

Cotterill, J. (Ed.). (2007). The language of sexual crime. Springer.

Delbecque, N., \& Gorp, L. V. (2015). The pseudo-copular use of the Spanish verbs hacerse and volverse: two types of change. CogniTextes. Revue de l'Association française de linguistique cognitive, (Volume 13).

Fotos, S., \& Ellis, R. (1991). Communicating about grammar: A task-based approach. TESOL Quarterly, 25(4), 605-628.

Gawlicki, M. C., McKown, S. M., Talbert, M. J., \& Brandt, B. A. (2014). Application of Bother in patient-reported outcomes instruments across cultures. Health and quality of life outcomes, 12(1), 18.

Gusmer, C. W. (1984). And you visited me: Sacramental ministry to the sick and the dying (Vol. 6). Liturgical Press.

Hartshorne, J. K., Pogue, A., \& Snedeker, J. (2015). Love is hard to understand: The relationship between transitivity and caused events in the acquisition of emotion verbs. Journal of child language, 42(3), 467-504.

Hellstén, M. (1994). 12 Cultural Values in Samish and Australian Children's Literature: A Corpus Linguistic Approach1. Researching Language and Literacy in Social Context: A Reader, 193.

Kang, C., \& Wu, X. (2015). The transitivity system and thematic meaning: a feminist-stylistics approach to Lawrence's Lady Chatterley's Lover. Theory and Practice in Language Studies, 5(6), 1200-1205.

Keita, S., \& Dyk, J. W. (2006). The Scene at the Threshing Floor: Suggestive readings and intercultural Considerations on ruth 3. The Bible Translator, 57(1), 17-32.

Kuperman, V., Estes, Z., Brysbaert, M., \& Warriner, A. B. (2014). Emotion and language: Valence and arousal affect word recognition. Journal of Experimental Psychology: General, 143(3), 1065 .

Lee, C. (1975). Embedded performatives. Language, 105-108.

Manning, E. (2002). Kissing and cuddling: the reciprocity of romantic and sexual activity. In Language and Desire (pp. 53-69). Routledge.

Ngezem, E. (2009). FROM CHAINS TO CHANGE: SEXUALITY AND SALVATION IN CHRISTINA ROSSETTI'S GOBLIN MARKET. Grove: Working papers on English studies, (16), 151-166.

Oraiby, H. H. (2011). Iraqi EFL Learners' Ability in Using Congratulations. Journal of College of Education for Pure Science, 1(5), 40-64.

Paradis, C. (2001). Adjectives and boundedness.

Ponsonnet, M. (2014). Figurative and non-figurative use of body-part words in descriptions of emotions in Dalabon (Northern Australia). International Journal of Language and Culture, 1(1), 98-130.

Rappaport Hovav, M., \& Levin, B. (1998). Building verb meanings. The projection of arguments: Lexical and compositional factors, 97-134.

Russell, J. A., \& Mehrabian, A. (1977). Evidence for a three-factor theory of emotions. Journal of research in Personality, 11(3), 273-294.

Stowe, L. A. (1985). Parsing WH-Constructions: Evidence for On-Line Gap Location. Working Papers in Linguistics, (11), 45-90. 
Struckman-Johnson, C., Struckman-Johnson, D., \& Anderson, P. B. (2003). Tactics of sexual coercion: When men and women won't take no for an answer. Journal of sex research, 40(1), 76-86.

Taavitsainen, I., \& Jucker, A. H. (2007). Speech act verbs and speech acts in the history of English. TOPICS IN ENGLISH LINGUISTICS, 52, 107.

van Valin Jr, R. D. (2006). Some universals of verb semantics. Linguistic universals, 155-178.

Warriner, A. B., Kuperman, V., \& Brysbaert, M. (2013). Norms of valence, arousal, and dominance for 13,915 English lemmas. Behavior research methods, 45(4), 1191-1207.

Werth, P. (1998). Tired and emotional: On the semantics and pragmatics of emotion verb complementation. Speaking of emotions: Conceptualization and expression, 409-441.

Yasuhito, N. A. G. A. I. A Preliminary Study on the Resistance Strategies of Female Adolescents against Assault by Confrontational Offender.

Yemelianova, O. V. (2013). Interiorized Self-evaluation as explication of self-concept. 